\title{
Analisis Pengaruh Self-efficacy, Kapabilitas, dan Perilaku Kerja Inovatif terhadap Kinerja
}

\author{
Vera Berliana \\ Tutuk Ari Arsanti \\ Universitas Kristen Satya Wacana Salatiga \\ Korespondensi penulis: tutuk.arsanti@staff.uksw.edu
}

Article Info:

Received 9 Februari 2018

Accepted 25 June 2018

Available online 30 June 2018

Abstract: The relative power of personal factors such as self-efficacy, capability, and innovative work behaviour in predicting performance was tested with 40 teachers through a survey. The variables' measurements are adapted from Avallone et al., (2007), Menon and Kohli (1999), Jong and Hartog (2008), and Campbell (1990). Path analysis were used to test the hypotheses. Our findings showed that all of hypotheses were accepted. The hypotheses stated that innovative work behaviour as a mediator variable were accepted in this study.

Keywords: Capability, Innovative work behaviour, Performance, Self-efficacy.

\section{PENDAHULUAN}

Penelitian terkait dengan kinerja individu dalam organisasi masih terus mendapatkan perhatian mengingat kinerja karyawan mempunyai dampak yang besar terhadap kinerja organisasi. Penelitian terdahulu menemukan sejumlah faktor yang dapat mempengaruhi kinerja individu secara langsung seperti kapabilitas individu (Byars, 1984; Snell, 1992), self-efficacy (Lee dan Bobko, 1994; Rahmi dkk, 2012; Mcdougall dan Kang, 2000; Luszczynska dkk., 2005; Cherian dan Jacob, 2013; Skaalvik, 2010), dan perilaku kerja inovatif yang dimiliki individu (Giovanni, 2014; Dorner, 2012; Vegt dan Janssen, 2003).

Berdasarkan penelitian terdahulu, persoalan kinerja individu dapat dijelaskan oleh kapabilitas, self-efficacy, dan perilaku inovatif yang dimiliki individu. Namun, sejumlah penelitian juga menjelaskan bahwa perilaku kerja inovatif itu sendiri dipengaruhi oleh self-efficacy dan kapabilitas individu (Avey et al., 2009; Peterson et al., 2009; dan Luthans et al., 2007). Dengan demikian, faktor kapabilitas dan self-efficacy tidak hanya dapat berpengaruh terhadap kinerja secara langsung, tetapi hal tersebut juga dapat berpegaruh secara tidak langsung terhadap kinerja yang dimediasi oleh variabel perilaku inovatif. Penelitian ini bertujuan untuk mengungkap pengaruh kapabilitas, self-efficacy, dan perilaku inovatif secara langsung terhadap kinerja dan menguji apakah variabel perilaku inovatif memediasi pengaruh kapabilitas dan self-efficacy terhadap kinerja.

Penelitian ini dilakukan tehadap para guru di Sekolah Luar Biasa (SLB), yaitu para guru yang dituntut untuk mempunyai perilaku inovatif karena adanya kebutuhan 
untuk mendidik dengan cara yang berbeda-beda sesuai apa yang diderita oleh anak didiknya (tuna grahita, tuna daksa, tuna netra, autis, dan tuna rungu). Hal tersebut membutuhkan kapabilitas, self-efficacy, dan perilaku inovatif guru SLB dalam mencapai kinerja yang baik. Berdasarkan latar belakang tersebut, sejumlah persoalan yang hendak diteliti adalah apakah terdapat pengaruh kapabilitas, self-efficacy, dan perilaku kerja inovatif terhadap kinerja secara parsial? Apakah kapabilitas dan self-efficacy berpengaruh terhadap perilaku inovatif secara parsial? Apakah perilaku kerja inovatif mampu memediasi pengaruh self-efficacy dan kapabilitas terhadap kinerja secara parsial?

\section{TELAAH TEORITIS}

\section{Pengaruh Kapabilitas terhadap Kinerja}

Kapabilitas merupakan proses mengaplikasikan kemampuan, pengetahuan, dan pengalaman yang dimiliki oleh sumber daya manusia untuk melaksanakan strategi pekerjaan yang telah ditetapkan dan dapat memberikan nilai bagi suatu organisasi (Day, 1994). Kapabilitas individu yang tinggi dapat berdampak pada kinerja yang tinggi. Oleh karenanya, strategi untuk meeningkatkan kapabilitas yang dapat menunjang kinerja cukup dibutuhkan (Menon et al., 1999). Individu yang terus belajar untuk mengembangkan kapabilitasnya dapat menjadi semakin trampil dan dapat mempengaruhi kinerjanya. Hal serupa ditemukan dalam sejumlah penelitian yang menyatakan bahwa kapabilitas kerja yang baik akan menghasilkan kinerja yang baik, semakin tinggi kapabilitas yang dimiliki seseorang, maka semakin tinggi pula kinerja yang dihasilkan (Menon et al., 1999; Enny, 2006; Kurniati dkk., 2012; Septiana dkk., 2012). Demikian pula, penelitian Byars (1984) menyatakan bahwa kesuksesan dalam menyelesaikan pekerjaan dipengaruhi oleh kapabilitas individu. Seiring dengan penelitian tersebut, Snell (1992) menjelaskan bahwa kapabilitas individu yang tinggi memungkinkan individu menggunakan waktu dan usaha yang lebih kecil daripada individu yang mempunyai kapabilitas rendah dalam menyelesaikan suatu pekerjaan. Mengacu pada sejumlah penelitian yang telah dilakukan sebelumnya, maka hipotesis pertama dirumuskan berikut ini.

H1: Kapabilitas berpengaruh positif terhadap kinerja.

\section{Pengaruh Self-efficacy terhadap Kinerja}

Self-efficacy merupakan keyakinan individu terhadap kemampuan individu sendiri untuk berhasil melakukan tugasnya dalam rangka mendapatkan hasil yang diinginkan. Self-efficacy menjadi salah satu faktor yang dapat menjelaskan kinerja individu seperti yang dinyatakan oleh Saugus (2016), yaitu self-efficacy sangat diperlukan dalam mengembangkan kinerja. Individu dengan self-efficacy yang tinggi dapat membantunya menyelesaikan pekerjaan yang diberikan. Dengan kata lain, semakin tinggi self-efficacy yang dimiliki individu, maka semakin tinggi kinerja yang akan dihasilkan. Hal tersebut terjadi karena individu akan memiliki keinginan untuk lebih maju dan lebih sukses dalam mencapai tujuannya akan meningkatkan kinerjanya. Dalam situasi sulit, orang yang memiliki self-efficacy rendah akan cenderung mudah menyerah. Sementara itu, orang yang memiliki self-efficacy yang tinggi akan berusaha lebih keras dan mencurahkan seluruh usaha dan perhatiannya untuk mengatasi tantangan atau pun 
mencapai tujuan yang ada (Lee dan Bobko,1994 dalam Engko, 2008). Penelitian terdahulu menemukan bahwa self-efficacy berpengaruh positif terhadap kinerja (Mcdougall dan Kang, 2000; Luszczynska dkk., 2005; Skaalvik, 2010; Rahmi dkk., 2012; Cherian dan Jacob, 2013). Berdasarkan penelitian yang telah dilakukan sebelumnya, maka hipotesis kedua dirumuskan berikut ini.

H2: Self-efficacy berpengaruh positif terhadap kinerja.

\section{Pengaruh Perilaku Kerja Inovatif terhadap Kinerja}

Menurut Jong \& Hartog (2008:5), perilaku kerja inovatif merupakan perilaku individu yang bertujuan untuk mengenalkan ide, proses, produk, atau prosedur baru dan berguna kepada kelompok atau organisasi. Perilaku kerja inovatif sangat dibutuhkan dalam pengembangan organisasi dan meningkatkan kinerja melalui perbaikan atau efisiensi berbagai aktifitas melalui inovasi yang dihasilkan. Hal tersebut sangat bergantung pada setiap individu dalam organisasi untuk merespon berbagai perubahan melalui perilaku inovatif dalam menghasilkan ide-ide kreatif dalam menggunakan metode kerja yang lebih efektif dan efisien (Yuan dan Woodman, 2010; Dorner, 2012; Vegt dan Janssen 2003). Hasil penelitian Dorner (2012) dan Vegt dan Janssen (2003) menunjukkan perilaku kerja inovatif berpengaruh positif secara signifikan terhadap kinerja karyawan. Lebih lanjut, perilaku kerja inovatif dapat mendorong organisasi dalam mencapai sasaran yang ditetapkan (Giovanni, 2014). Berdasarkan penelitian terdahulu, hipotesis ketiga dirumuskan berikut ini.

H3: Perilaku kerja inovatif berpengaruh positif terhadap kinerja.

\section{Pengaruh Kapabilitas dan Self-efficacy terhadap Perilaku Kerja Inovatif}

Sejumlah penelitian menunjukkan bahwa kapabilitas menjadi salah satu tolok ukur keberhasilan seseorang di dalam meningkatkan kreatifitas demi tercapainya kesuksesan suatu organisasi. Dengan memiliki orientasi kapabilitas yang kuat, maka seseorang akan terus berusaha meningkatkan perilaku inovatifnya demi menunjang pekerjaannya dan memberikan hasil yang terbaik (Aggarwal 1997). Oleh karena itu, organisasi perlu untuk mengidentifikasi kemampuan kunci individu yang mengarah pada keberhasilan. Dengan demikian, individu dalam organsiasi akan memiliki nilai tambah yang berharga bagi organisasi (Calantone dkk., 2002; Neely dan Hii, 1998; Palangkaraya dkk., 2010; Salaman dan Storey, 2002; Thornhill, 2006).

Bandura (1997) juga menjelaskan bahwa perilaku kerja inovatif juga dijelaskan oleh self-efficacy. Individu dengan self-efficacy yang tinggi dapat lebih siap bereksperimen melalui perilaku kerja inovatifnya untuk kemudian menerapkan dalam lingkungan kerjanya. Kumar dan Uzkurt (2010) menyatakan bahwa individu dengan tingkat self-efficacy yang tinggi cenderung memiliki keyakinan yang lebih tinggi dalam kemampuan mereka untuk membuat perubahan-perubahan. Beberapa hasil penelitian terdahulu menyatakan bahwa seseorang dengan self-efficacy yang kuat akan menghasilkan perilaku kerja inovatif yang lebih tinggi (Hsiao dkk., 2011; Wahyuningrum dkk., 2012; dan Momeni dkk., 2014). Berdasarkan penelitian-penelitian yang telah dilakukan sebelumnya, maka hipotesis keempat dan kelima dirumuskan berikut ini. 
H4: Kapabilitas berpengaruh positif terhadap perilaku kerja inovatif.

H5: Self-efficacy berpengaruh positif terhadap perilaku kerja inovatif.

\section{Perilaku Kerja Inovatif sebagai Variabel Mediator}

Berdasarkan penelitian-penelitian yang telah diuraikan di atas menjelaskan bahwa kapabilitas, self-efficacy, dan perilaku kerja inovatif mempunyai pengaruh secara langsung terhadap kinerja. Namun, penelitian lain juga menjelaskan bahwa faktor kapabilitas dan self-efficacy juga memiliki pengaruh terhadap perilaku kerja inovatif. Dengan demikian, variabel perilaku kerja inovatif sendiri berpotensi sebagai variabel mediator pada pengaruh kapabiltas dan self-efficacy terhadap kinerja. Berdasarkan penjelasan tersebut di atas, hipotesis keenam dan ketujuh dirumuskan berikut ini.

H6: Perilaku kerja inovatif memediasi pengaruh kapabilitas terhadap kinerja.

H7: Perilaku kerja inovatif memediasi pengaruh self-efficacy terhadap kinerja.

\section{Model Penelitian}

Berdasarkan hipotesis yang telah dirumuskan, pengaruh antarvariabel dapat digambarkan dalam bentuk model penelitian sebagai berikut:

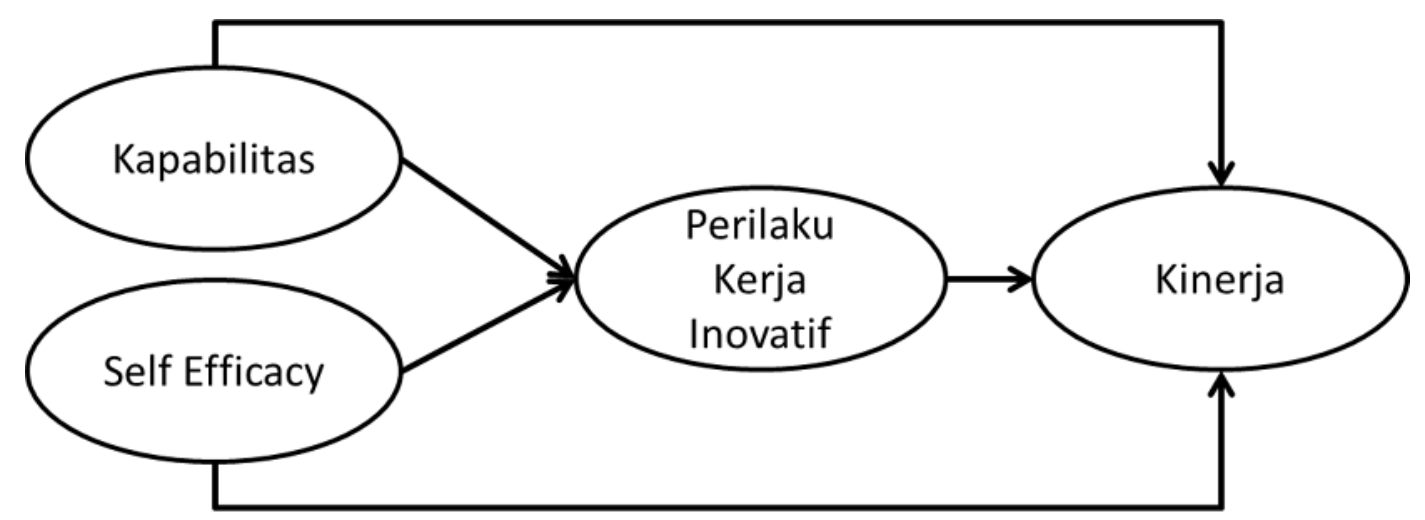

\section{Gambar 1. Model Penelitian}

\section{METODE PENELITIAN}

Penelitian ini merupakan penelitian kuantitatif, sehingga dalam penelitian ini menggunakan data berupa angka yang diperoleh dari survei. Populasi penelitian ini meliputi keseluruhan guru SLB Negeri di wilayah Salatiga yang berjumlah 40 orang. Metode sensus digunakan dalam pengumpulan data, yaitu penelitian mengambil satu kelompok populasi sebagai sampel secara keseluruhan.

\section{Metode Pengumpulan Data}

Survei digunakan dalam pengumpulan data. Alat ukur yang digunakan untuk mengukur self-efficacy diadopsi dan dimodifikasi dari Avallone et al., (2007) dengan skala yang digunakan dari 1 sampai 5 yang menunjukkan dari pendapat Sangat Tidak 
Setuju (STS) sampai dengan Sangat Setuju (SS). Alat ukur untuk kapabilitas diadopsi dan dimodifikasi dari Menon dan Kohli (1999) dengan skala yang digunakan adalah 1 sampai 5 yang menunjukkan dari Sangat Tidak Setuju (STS) sampai Sangat Setuju (SS). Alat ukur untuk mengukur perilaku kerja inovatif diadopsi dari De Jong dan Den Hartog (2008) dengan skala yang digunakan dalam variabel ini adalah Skala Likert dari 1 sampai 5 yang menunjukkan dari Tidak Setuju (TS) sampai Sangat Setuju (SS), sedangkan alat ukur kinerja diadopsi dari Campbell (1990) dengan skala 1 sampai 5 yang menunjukkan dari Tidak Setuju (TS) sampai Sangat Setuju (SS).

Uji validitas dan reliabilitas dilakukan untuk mendapatkan data yang valid dan reliabel sebelum data dianalisis lebih lanjut. Item kuesioner dinyatakan valid apabila nilai pearson correlation berbintang dua dengan tingkat signifikansi pada level $5 \%$, sedangkan untuk reliabilitas menggunakan Cronbach Alpha $>0,60$ untuk bisa dikatakan reliable untuk pengukuran dan penelitian lebih lanjut.

\section{Alat Analisis Data}

Metode analisis data yang digunakan dalam penelitian ini adalah analisis jalur (path analysis) yang merupakan bagian dari analisis regresi linier yang digunakan untuk menganalisis hubungan kausal antarvariabel, yaitu variabel-variabel bebas yang mempengaruhi variabel tergantung, baik secara langsung maupun tidak langsung melalui satu atau lebih perantara (Ghozali, 2001:149). Sebelum dilakukan analisis data, uji asumsi klasik dilakukan terlebih dahulu. Berikut hasil uji asumsi klasik yang telah dilakukan:

\section{a. Uji Multikolinearitas}

Dalam pengujian ini, peneliti melakukan uji multikolinearitas dengan menggunakan metode auxiliary sesuai yang dijelaskan oleh Bawono (2006). Berikut hasil regresi antarvariabel dengan hasil uji regresi utama:

\section{Perilaku kerja inovatif sebagai variabel dependen}

Tabel 1. Hasil $\mathbf{R}^{2}$ (Koefisien determinasi majemuk) regresi utama

\begin{tabular}{|l|r|r|r|r|}
\hline Model & \multicolumn{1}{|c|}{ R } & R Square & $\begin{array}{c}\text { Adjusted R } \\
\text { Square }\end{array}$ & $\begin{array}{c}\text { Std. Error of } \\
\text { the Estimate }\end{array}$ \\
\hline 1 & $.952^{\mathrm{a}}$ & .907 & .902 & 2.73999 \\
\hline
\end{tabular}

a. Predictors: (Constant), X2, X1

Tabel 2. Perbandingan $\mathbf{r}^{2}$ dan $\mathbf{R}^{2}$

\begin{tabular}{lc}
\multicolumn{1}{c}{ Variabel Independen } & $\mathbf{r}^{\mathbf{2}}$ \\
\hline Self-efficacy $=\mathrm{f}($ Kapabilitas $)$ & 0.863 \\
\hline Kapabilitas $=\mathrm{f}($ Self-efficacy) & 0.863 \\
\hline \multicolumn{2}{c}{$\mathbf{R}^{2}=\mathbf{0 . 9 0 2}$} \\
\hline
\end{tabular}

Sumber: Data primer yang diolah, Juli 2017. 
Tabel 1 dan 2 di atas menunjukkan bahwa $\mathrm{R}^{2}$ dari regresi lebih besar dari nilai $\mathrm{r}^{2}$, sehingga dinyatakan variabel self-efficacy dan variabel kapabilitas yang dipakai untuk penelitian ini tidak memiliki gejala multikolinieritas.

\section{Kinerja sebagai variabel Dependen}

Tabel 3. Hasil $R^{2}$ (Koefisien determinasi majemuk) regresi utama

Model Summary

\begin{tabular}{|l|r|r|r|r|}
\hline Model & \multicolumn{1}{|c|}{ R } & R Square & $\begin{array}{c}\text { Adjusted R } \\
\text { Square }\end{array}$ & $\begin{array}{l}\text { Std. Error of } \\
\text { the Estimate }\end{array}$ \\
\hline 1 & $.991^{\mathrm{a}}$ & .983 & .981 & 1.10240 \\
\hline
\end{tabular}

a. Predictors: (Constant), Y1, X2, X1

Tabel 4. Perbandingan $\mathbf{r}^{2}$ dan $\mathbf{R}^{2}$

\begin{tabular}{lc}
\multicolumn{1}{c}{ Variabel Independen } & $\mathbf{r}^{\mathbf{2}}$ \\
\hline Inovatif $=\mathrm{f}($ Self Efficacy,kapabilitas) & 0.902 \\
\hline Self Efficacy $=\mathrm{f}$ (Kapabilitas, Inovatif) & 0.908 \\
\hline Kapabilitas $=\mathrm{f}$ (Self Efficacy,Inovatif) & 0.880 \\
\hline \multicolumn{2}{c}{$\mathbf{R}^{\mathbf{2}}=\mathbf{0 . 9 8 1}$} \\
\hline
\end{tabular}

Sumber: Data primer yang diolah, Juli 2017.

Tabel 3 dan 4 di atas menunjukkan bahwa $\mathrm{R}^{2}$ dari regresi lebih besar dari nilai $\mathrm{r}^{2}$ variabel perilaku kerja inovatif, self-efficacy, dan kapabilitas, sehingga penelitian ini terdeteksi tidak adanya gejala multikolinieritas.

\section{b. Uji Heteroskedastisitas}

Uji Heteroskedastisitas dilakukan dengan menggunakan White Test, uji ini dilakukan dengan meregres residual kuadrat $\left(\mathrm{Ui}^{2}\right)$ dengan variabel bebas dan perkalian variabel bebas.

\section{Tabel 5a. Hasil Uji Heteroskedastisitas Perilaku Kerja Inovatif sebagai Variabel Dependen}

\begin{tabular}{|l|r|r|r|r|}
\hline \multicolumn{1}{|c|}{ Model Summary } \\
\hline 1 & \multicolumn{1}{|c|}{ R } & R Square & $\begin{array}{c}\text { Adjusted R } \\
\text { Square }\end{array}$ & $\begin{array}{l}\text { Std. Error of } \\
\text { the Estimate }\end{array}$ \\
\hline
\end{tabular}

a. Predictors: (Constant), Jumlah_X1danX2, X1_2, X2_2, X2 
Dengan mengetahui nilai Adj- $\mathrm{R}^{2}$ sebesar 0,198, maka dapat diketahui besarnya $\chi^{2}$ hitung, yaitu $0,198 * 40=7.92$, sedangkan besarnya $\chi^{2}$ tabel adalah 50,99. Karena $\chi^{2}$ hitung $<\chi^{2}$ tabel, maka gejala heteroskedastisitas dalam model persamaan ini tidak ada.

\section{Tabel 5b. Hasil Uji Heteroskedastisitas Kinerja sebagai variabel dependen}

\begin{tabular}{|l|r|r|r|r|}
\hline Model & \multicolumn{1}{|c|}{ R } & R Square & $\begin{array}{l}\text { Adjusted R } \\
\text { Square }\end{array}$ & $\begin{array}{l}\text { Std. Error of } \\
\text { the Estimate }\end{array}$ \\
\hline 1 & $.732^{\mathrm{a}}$ & .537 & .452 & 1.23226 \\
\hline
\end{tabular}

a. Predictors: (Constant), jumlah_x1x2dany1, Y1_2, X1_2, X2_2, X1, X2

Dengan mengetahui nilai Adj- $\mathrm{R}^{2}$ sebesar 0,452, maka dapat diketahui besarnya $\chi^{2}$ hitung, yaitu $0.452 * 40=18,08$, sedangkan besarnya $\chi^{2}$ tabel adalah 50,99. Karena $\chi^{2}$ hitung $<\chi^{2}$ tabel, maka gejala heteroskendastisitas dalam model persamaan tidak ada.

\section{c. Uji Normalitas}

Uji normalitas dilakukan untuk menguji apakah variabel independen dan variabel dependen dalam model regresi memiliki distribusi normal atau tidak (Bawono, 2006). Hasil uji normalitas menunjukkan bahwa data dalam penelitian ini terdistribusi normal.

\section{HASIL DAN PEMBAHASAN}

\section{Hasil Uji Hipotesis}

\section{Pengaruh Kapabilitas terhadap Kinerja}

Hasil statistik menunjukkan bahwa tingkat kapabilitas seseorang yang tinggi akan mempengaruhi kinerja yang akan diselesaikan. Tabel 6 menunjukkan bahwa kapabilitas berpengaruh terhadap kinerja yang ditunjukkan dengan nilai $t$ hitung sebesar 5,240 dengan sig < 0,05 yang berarti H1 diterima.

\section{Pengaruh Self-efficacy terhadap Kinerja}

Hasil statistik menunjukkan bahwa tingkat self-efficacy seseorang yang tinggi akan mempengaruhi kinerja yang akan diselesaikan. Tabel 6 menunjukkan bahwa self-efficacy berpengaruh terhadap kinerja. Hal tersebut ditunjukkan dengan nilai $\mathrm{t}$ hitung sebesar 4,559 dengan sig $<0,05$ yang berarti $\mathrm{H} 2$ diterima.

\section{Pengaruh Perilaku Kerja Inovatif terhadap Kinerja}

Hasil statistik menunjukkan bahwa seseorang yang memiliki tingkat perilaku kerja inovatif dalam menciptakan suatu gagasan yang baru dapat meningkatkan hasil kinerja yang baik. Tabel 6 menunjukkan bahwa perilaku kerja inovatif berpengaruh terhadap kinerja. Hal tersebut ditunjukkan dengan nilai t hitung sebesar 4,682 dengan sig $<0,05$ yang berarti $\mathrm{H} 3$ diterima. 


\section{Pengaruh Kapabilitas terhadap Perilaku Kerja Inovatif}

Hasil statistik menunjukkan bahwa semakin tinggi kapabilitas individu menandakan bahwa ia mampu untuk menciptakan metode baru. Tabel 6 menunjukkan bahwa kapabilitas berpengaruh terhadap perilaku kerja inovatif. Hal tersebut ditunjukkan dengan nilai t hitung sebesar 2,586 dengan sig $<0,05$ yang berarti $\mathrm{H} 4$ diterima.

Tabel 6. Hasil Perhitungan Statistik

\begin{tabular}{|c|c|c|c|c|c|c|}
\hline No & $\begin{array}{c}\text { Variabel } \\
\text { Terikat } \\
\end{array}$ & Variabel Bebas & t hitung & $\beta$ & Sig & Keterangan \\
\hline \multirow{4}{*}{1} & \multirow{3}{*}{ Kinerja } & Kapabilitas & 5.240 & 0.341 & 0.000 & H1 Diterima \\
\hline & & Self-efficacy & 4.559 & 0.338 & 0.000 & H2 Diterima \\
\hline & & $\begin{array}{l}\text { Perilaku Kerja } \\
\text { Inovatif }\end{array}$ & 4.682 & 0.335 & 0.000 & H3 Diterima \\
\hline & $\begin{array}{l}\text { Adjusted } \mathrm{R}^{2} \\
\text { Sig } \\
\text { F hitung }\end{array}$ & $\begin{array}{l}=98.1 \% \\
=0.000 \\
=683.803\end{array}$ & & & & \\
\hline \multirow{3}{*}{2} & \multirow{2}{*}{$\begin{array}{l}\text { Perilaku } \\
\text { Kerja } \\
\text { Inovatif }\end{array}$} & Kapabilitas & 2.586 & 0.355 & 0.014 & H4 Diterima \\
\hline & & Self-efficacy & 4.466 & 0.613 & 0.000 & H5 Diterima \\
\hline & $\begin{array}{l}\text { Adjusted } R^{2} \\
\text { Sig } \\
\text { F hitung }\end{array}$ & $\begin{array}{l}=90.2 \% \\
=0.000 \\
=179.689\end{array}$ & & & & \\
\hline
\end{tabular}

\section{Pengaruh Self-efficacy terhadap Perilaku Kerja Inovatif}

Hasil perhitungan statistik menunjukkan bahwa semakin tinggi self-efficacy yang dimiliki oleh seorang individu, maka semakin tinggi pula perilaku kerja inovatif yang diciptakan. Tabel 6 menunjukkan bahwa self-efficacy berpengaruh terhadap perilaku kerja inovatif. Hal tersebut ditunjukkan melalui nilai t hitung sebesar 4,466 dengan sig < 0,05 yang berarti H5 diterima.

\section{Analisis Variabel Perilaku Kerja Inovatif sebagai Variabel Mediator}

1. Perilaku Kerja Inovatif sebagai mediator dalam pengaruh Kapabilitas terhadap Kinerja

Hubungan langsung kapabilitas dengan kinerja ditunjukkan dengan hasil analisis statistik sebesar 0,341, sedangkan hubungan kapabilitas dengan kinerja melalui perilaku kerja inovatif sebagai variabel mediasi ditunjukkan dengan nilai 0,355 dan 0,335 . Nilai hubungan tidak langsung menunjukkan nilai sebesar 0,118 yaitu perkalian dari 0,355 dan 0,335. Dengan demikian, H6 dapat diterima.

2. Perilaku Kerja Inovatif sebagai mediator dalam pengaruh Self-efficacy terhadap Kinerja 
Hubungan langsung self-efficacy dengan kinerja ditunjukkan dengan hasil analisis statistik sebesar 0,338 , sedangkan hubungan self-efficacy dengan kinerja melalui perilaku kerja inovatif sebagai variabel mediasi ditunjukkan dengan nilai 0,613 dan 0,335 . Nilai hubungan tidak langsung menunjukkan nilai sebesar 0,205 yaitu perkalian dari 0,613 dan 0,335. Dengan demikian, H7 dapat diterima.

\section{Pembahasan}

Dari hasil analisis statistik, data menunjukkan bahwa pengaruh self-efficacy terhadap perilaku kerja inovatif memberikan hasil yang positif. Hasil analisis tersebut diekspresikan melalui tanggapan mereka akan keyakinan mereka atas kemampuan mereka dalam melaksanakan tugas yang diberikan, bekerja sesuai program kerja yang telah ditentukan, kemampuan belajar menggunakan program belajar mengajar yang baru, bisa berkonsentrasi dalam menyelesaikan suatu pekerjaan, dapat bekerjasama dengan rekan kerja, dan bisa menjalin hubungan yang baik dengan atasan maupun

murid. Berdasarkan hal tersebut, maka dapat dipahami bahwa guru yang memiliki tingkat self-efficacy yang tinggi dapat berdampak pada perilaku inovatifnya. Hasil ini didukung oleh hasil penelitian dari Hsiao et al., (2011), Wahyuningrum et al., (2012), dan Momeni et al., (2014) yang menyatakan bahwa self-efficacy berpengaruh positif terhadap perilaku kerja inovatif.

Hasil pengujian pengaruh langsung secara statistik menyatakan bahwa kapabilitas berpengaruh positif terhadap perilaku kerja inovatif. Hasil tersebut dapat dibuktikan dari tanggapan responden melalui kuesioner, yaitu dari 10 butir pernyataan responden memberikan jawaban yang positif. Sejauh ini, guru di SLB Negeri ini sudah mampu membantu gerakan psikomotorik peserta didik, mampu melaksanakan kegiatan belajar dan mengajar secara efektif, mampu menganalisis hasil belajar siswa dengan tepat, mampu memahami materi ajar yang ada di dalam kurikulum sekolah, dan mampu menguasai landasan teori pendidikan bagi siswa dengan baik. Hipotesis ini mendukung penelitian yang dilakukan oleh Giovanni (2014).

Pada hipotesis ketiga, hasil pengujian secara statistik menyatakan bahwa perilaku kerja inovatif berpengaruh secara signifikan terhadap kinerja guru di SLB Negeri Salatiga. Dilihat dari respon guru SLB Negeri saat mengisi kuesioner, hasilnya mereka menjawab dengan nilai positif. Artinya, guru di sekolah tersebut bersedia mencari metode kerja yang baru, bersedia mencari solusi untuk memecahkan suatu masalah, selalu menerima ide inovatif dalam organisasi, bersedia memperkenalkan ideide inovatif ke dalam praktik kerja, dan bersedia mengembangkan hal baru dalam suatu pekerjaan. Semakin tinggi perilaku kerja inovatif yang dilakukan oleh seorang guru, maka kinerja yang dihasilkan semakin meningkat. Karena perilaku kerja guru yang jauh dari inovatif, tentunya akan menghambat tercapainya kinerja yang akan dihasilkan. Untuk mendorong perilaku kerja yang inovatif, guru harus didorong secara aktif mencari peluang untuk perbaikan dan perubahan. Untuk itu, lingkungan kerja sebaiknya sering mengadakan pelatihan bagi karyawannya baik soft-skill maupun hard-skill. Hipotesis ini mendukung penelitian yang dilakukan oleh Hsiao et al. (2011), Dorner (2012), dan Vegt dan Janssen (2003).

Pada hipotesis keempat, hasil pengujian secara statistik menyatakan self-efficacy berpengaruh positif terhadap kinerja guru di SLB Negeri Kota Salatiga. Karena selfefficacy memiliki pengaruh besar dalam mewujudkan kemampuan atau keinginan yang besar dalam melakukan tugas sebagai seorang guru mulai dari awal perencanaan 
pembelajaran, proses dan hasil akhir pembelajaran disiapkan secara mendasar, sehingga pengaruh self-efficacy berperan sekali dalam meningkatkan kinerja guru. Hal tersebut menjadi dasar bahwa variabel self-efficacy mempunyai pengaruh positif dalam kinerja guru. Hasil ini mendukung penelitian Rahmi, dkk. (2012), Mcdougall \& Kang (2000), Luszczynska et al. (2005), dan Cherian dan Jacob (2013) yang menyatakan bahwa selfefficacy berpengaruh positif terhadap kinerja guru. Penelitian Mcdougall dan Kang (2000), Luszczynska et al., (2005), dan Cherian dan Jacob (2013) menyatakan bahwa self-efficacy guru berpengaruh positif secara signifikan terhadap kinerja guru.

Pada hipotesis kelima, hasil pengujian secara statistik menyatakan bahwa kapabilitas berpengaruh positif dan signifikan terhadap kinerja guru di SLB Negeri Kota Salatiga. Jadi, hasil tersebut menyimpulkan bahwa semakin tinggi derajat kapabilitas, kinerja semakin meningkat. Dengan kata lain, semakin tinggi derajat kapabilitas, maka akan memberikan dampak positif terhadap peningkatan kinerja. Artinya, kapabilitas kerja yang tinggi dapat meningkatkan kinerja guru. Seperti penelitian yang dilakukan oleh Septiani (2014), yaitu semakin tinggi tingkat kapabilitas yang dimiliki, semakin tinggu kinerja yang dihasilkan. Hipotesis ini mendukung penelitian yang dilakukan oleh Enny (2006), Kurniati et al. (2012), dan Anil Menon et al. (1999).

Pada hipotesis keenam, hasil pengujian secara statistik menunjukkan bahwa selfefficacy berpengaruh positif dan signifikan terhadap kinerja melalui variabel perilaku kerja inovatif. Artinya, perilaku kerja inovatif turut serta berperan dalam menyelesaikan suatu pekerjaan. Semakin tinggi sikap self-efficacy individu dalam menciptakan suatu gagasan ide baru terhadap pekerjaannya, maka kinerja yang dihasilkan semakin baik. Selanjutnya, perilaku kerja inovatif mampu menjadi variabel mediator dalam pengaruh self-efficacy terhadap kinerja.

Pada hipotesis ketujuh, pengaruh secara tidak langsung kapabilitas terhadap kinerja melalui variabel perilaku kerja inovatif berpengaruh positif secara sginifikan. Semakin tinggi kapabilitas yang dimiliki oleh seseorang akan memunculkan ide atau gagasan baru untuk menunjang suatu pekerjaan yang akan diselesaikan. Inovasi berasal dari ide-ide yang datang dari kapabilitas orang-orang yang ada, berbeda dengan orang yang mempunyai kapabilitas rendah. Ia akan menyelesaikan suatu pekerjaannya saja tanpa memikirkan ide atau gagasannya dengan membutuhkan waktu yang lebih besar.

\section{KESIMPULAN DAN SARAN}

\section{Kesimpulan}

1. Self-efficacy berpengaruh secara positif terhadap kinerja guru. Semakin besar selfefficacy yang dimiliki oleh seorang guru dalam proses belajar dan mengajar, maka semakin besar kinerja yang akan dihasilkan.

2. Perilaku kerja inovatif berpengaruh secara positif terhadap kinerja guru. Semakin tinggi perilaku kerja inovatif yang dihasilkan, maka kinerja yang dihasilkan juga semakin meningkat.

3. Kapabilitas berpengaruh secara positif terhadap kinerja. Semakin tinggi kapabilitas seorang individu, maka semakin tinggi pula kinerja yang dihasilkan.

4. Kinerja secara langsung berpengaruh positif terhadap self-efficacy, kapabilitas, dan perilaku kerja inovatif, sedangkan analisis secara tidak langsung terhadap kinerja juga berpengaruh terhadap self-efficacy melalui variabel perilaku kerja inovatif 
sebagai mediator dan kinerja berpengaruh positif dari pengaruh kapabilitas melalui variabel perilaku kerja inovatif sebagai mediator.

5. Dari hasil hubungan langsung dan tidak langsung antara self-efficacy dan kinerja menyatakan nilai tertinggi sebesar 0,338 yang menunjukkan bahwa kinerja dipengaruhi oleh self-efficacy secara langsung.

6. Dari hasil hubungan langsung dan tidak langsung antara kapabilitas dan kinerja menyatakan nilai tertinggi sebesar 0,341 yang menunjukkan bahwa kinerja dipengaruhi oleh kapabilitas secara langsung.

7. Variabel dominan yang mempengaruhi kinerja adalah variabel self-efficacy yaitu sebesar 0,613 .

\section{Saran}

Untuk masa mendatang, penelitian selanjutnya diharapkan dapat mempertimbangkan karakteristik individunya (misalnya, pegawai baru dengan pegawai lama, jenis kelamin, lama bekerja individu, dan lain-lain) yang dapat berdampak terhadap self-efficacy pada individu karyawan. Implikasi yang dapat diperoleh dari hasil penelitian ini adalah:

\section{Implikasi Terapan}

Bahwasanya, proses belajar pada siswa-siswi SLB tergantung pada keyakinan pada diri seorang guru. Apakah mereka yakin dapat menggunakan program belajar kerja yang baru dan mengembangkan serta menggunakan pengetahuan teknis di dalam menjalankan pekerjaan seorang guru. Setelah mendapati hasil dari proses belajar dan mengajarnya, seorang guru dituntut untuk menganalisis hasil belajar siswa dengan tepat.

\section{Implikasi Teoritis}

Penelitian terdahulu belum menempatkan variabel perilaku kerja inovatif sebagai mediator dan kondisi itulah yang menjadi pembeda penelitian ini dengan penelitian sebelumnya. Penelitian ini menjadikan variabel perilaku kerja inovatif sebagai variabel mediator dan hasilnya bisa diterima bahwa variabel tersebut mampu menjadi mediator dari pengaruh self-efficacy dan kapabilitas terhadap kinerja melalui perilaku kerja inovatif.

\section{DAFTAR REFERENSI}

Agarwal, R. \& Prasad, J. (1997). A Conceptual and Operational Definition of Personal Innovativeness in the Domain of Information Technology. Information Systems Research 9 (2): 204-215.

Akdon, R. (2007). Rumus dan Data dalam Aplikasi Statistika. Bandung: Alfabeta.

Anonim. Peraturan Pemerintah Nomor 74 Tahun 2008 tentang Guru.

Avalone, F., Pepe, S. J., Luisa, M. \& Vecchione, M. (2010). Work self-efficacy scale and search for work self-efficacy scale: A Validation Study in Spanish and Italian Cultural Contexts.

Avey, J. B., Luthans, F., \& Jensen, S. M. (2009). Psychological Capital: A Positive Resource for Combating Employee Stress and Turnover. Human Resource Management 48 (5), 677-693. 
Bandura, A. (1997). Self-Efficacy: The Exercise of Control. New York: W. H. Freeman and Company.

Bawono, A. (2006). Multivariate Analysis dengan SPSS. Salatiga: STAIN Salatiga Press.

Byars (1984). Manajemen Sumber Daya Manusia, Yogyakarta: Andi Offset.

Calantone, R. J., Cavusgil, S. T., \& Yushan, Z. (2002). Learning orientation, firm innovation capability, and firm performance. Industrial Marketing Management 31 (6), 515-524.

Cherian \& Jacob. (2013). Impact of Self-Efficacy on Motivation and Performance of Employees. International Journal of Business and Management, Vol 8 No 14.

Campbell, R. M. \& Brue, S. L. (1990). Economics: Principles, Problems and Policies. McGraw-Hill Publishing Company.

Day, G. S. (1994). The Capabilities of Market-Driven Organizations. Journal of Marketing 58 (October), 37-52.

De Jong, Jeroen, P. J., \& Den Hartog, Deane, N. (2008). Innovative Work Behavior: Measurement and Validation. SCALES. Zoetermeer.

Departemen Pendidikan Nasional (2005). Undang-Undang Nomor 14 Tahun 2005 tentang Guru dan Dosen. Jakarta: Depdiknas RI.

Dorner, N. (2012). Innovative work behavior: The roles of employee expectations and effects on job performance.

Ghozali, I. (2001). Analisis Multivariate dengan Program SPSS. Semarang: Badan Penerbit Universitas Diponegoro.

Hadi, S. (1991). Dasar Metode Research. Jilid I. Yogyakarta: Andi Offset.

Hsiao, H. C., Chang, J. C., Tu, Y. L., \& Chen, S. C. (2011). The Impact of Self-Efficacy on Innovative Work Behavior for Tearchers. International Journal of Social Science and Humanity, Vol 1 No1 (May).

Kurniati, W. \& Kuswinarmo (2012). Pengaruh Kemampuan dan Motivasi Karyawan terhadap Kinerja Karyawan Kontrak pada PT Sapta Pusaka Graha Nusantara (SPGN) Surabaya. Jurnal Ekonomi.

Lee, C. \& Bobko, P. (1994). Self-Efficacy Belief: Comparation of Measures. Journal of Applied Psychology 79, 506-517.

Luszczynska et al. (2005). General Self-Efficacy in Various Domains of Human Functioning: Evidence from Five Countries. International Journal of Psychology 40 (2), 80-89.

Luthans, F., Bruce, J. A., James, B. A., \& Steven, M. N. (2007). Positive Psychological Capital: Measurement and Relationship with Performance and Satisfaction. Personnel Psychology 60, 541-572.

Mariade, S. (2016). Pengaruh Self-Efficacy, Internal Locus of Control, dan Kepuasan Kerja terhadap Kinerja Guru Madrasah di Kabupaten Kaur. Skripsi.

Mcdougall \& Kang (2008). Memory Self-Efficacy and Memory Performance in Older Males. Austin: The University of Texas.

Menon, A., Bharadwaj, S. G., Adidam, P. T., \& Edison, S. W. (1999). Antecendents and Consequences of Marketing Strategi Making: A Model and a Test. Journal of Marketing, Vol 63 (April), 18-40.

Momeni, M., Ebrahimpour, H., \& Ajirloo, M. B. (2014). The Effect of Employees selfefficacy on innovative work behavior at social security organization employees in ardabil province. Journal of Business and Management, Vol 3 No 8 (April). 
Neely, A. \& Hii, J. (1998). Innovation and business performance: a literature review. The Judge Institute of Management Studies. University of Cambridge.

Palangkaraya, A., Stierwald, A., Webster, E., \& Jensen, P. (2010). Examining the Characteristics of Innovative Firms in Australia. A Report for the Australian Government Department of Innovation, Industry, Science and Research, Intellectual Property Research Institute of Australia Report. The University of Melbourne.

Rahmi, E. R., Yusuf, M. \& Ptiyatama, A. N. (2012). The Relationship between Intrinsic Motivation and Self-Efficacy with Job Involment on the Employees in Garment. Jurnal Psikologi.

Rachmawati, E., Warella, Y., \& Hidayat, Z. (2006). Pengaruh Motivasi Kerja, Kemampuan Kerja dan Gaya Kepemimpinan Terhadap Kinerja Karyawan Pada Badan Kesatuan Bangsa dan Perlindungan Masyarakat Propinsi Jawa Tengah. Jurnal Ilmu Administrasi dan Kebijakan Publik, Vol 3, 89-97.

Salaman, G. \& Storey, J. (2002). Manager's Theories About the Process of Innovation. Journal of Management Studies, Vol 39 Iss 2 (March).

Shafiah, S. A., Siswidiyanto, \& Prasetyo, W. Y. (2012). Pengaruh Kemampuan dan Motivasi Terhadap Kinerja Pegawai Kantor Pelayanan Terpadu. Jurnal Administrasi Publik, Vol 2, 312-318.

Skaalvik, E. M. \& Skaalvik, S. (2010). Teacher self-efficacy and teacher burnout : A study of relations. Teaching and Teacher Education, Vol 26 No 1, 1059-1069.

Snell, S. A. \& Dean, J. W. Jr. (1992). Integrated Manufacturing and Human Resource Management: A Human Capital Perspective. Academy of Management Journal 35, 467-504.

Sugiyono (2006). Metode Penelitian Kuantitatif, Kualitatif dan R\&D. Bandung: Alfabeta.

Sugiyono (2008). Metode Penelitian Bisnis. Bandung: Alfabeta.

Thornhill, S. (2006). Knowledge, Innovation, and Firm Performance in high-and lowtechnology regimes. Journal of Business Venturing, Vol 21 Iss 5, 687-703.

Umar, H. (2001). Metode Penelitian dan Aplikasi dalam Pemasaran. Jakarta: PT Gramedia Pustaka Umum.

Undang-Undang Nomor 20 Tahun 2003 tentang Sistem Pendidikan Nasional.

Uzkurt, C., Kumar, R., Kimzan, H. S., \& Eminoglu, G. (2013). Role of Innovation in the Relation between Organizational Culture and Firm.

Van der Vegt, G. S. \& Janssen, O. (2003). Joint impact of interdependence and group diversity on innovation. Journal of Management 29, 729-751.

Wahyuningrum, S. M., Widianto, S. \& Abdulah, R. (2012). Dampak Self-Efficacy terhadap Perilaku Inovasi Apoteker di Rumah Sakit. Jurnal Farmasi Klinik Indonesia, Vol 1 No 2 (Juni).

Yuan, F. R., \& Woodman, R. W. (2010). Innovative Behavior in The Workplace: The Role of Performance and Image Outcome Expectations. Academy of Management Journal 53 (2), 323-342. 